\title{
Machines of Turning Actions into Reactions: The German Novella and the Event \\ Fritz Breithaupt
}

Department of Germanic Studies, Indiana University, Bloomington, IN, USA

This essay examines features of the German Romantic novella and discusses the cognitive work the novella does. The novella presents an unheard-of event, but does so in such a way which induces the reader to find an appropriate context explicating and rationalizing the event so that it "makes sense." As a result, the event loses its quality of being a true and radical event. The radical event is thus both posited and undermined by the novella. The search for context, while the work of the reader, is prefigured by the novella through various contextualizations, justifications, and inquiries already occurring in the text. This essay proposes a cultural dynamic of transforming actions into reactions as the cause for the popularity of the novella in Germany. When actions can be explained as mere reactions, the novella can be seen as operating in the service of a self, a construct under pressure to excuse itself and to limit its responsibility. The article ends with considerations about the evolutionary origins of fiction.

This essay addresses the peculiar and improbable rise of the novella in Romanticism, especially in Germany (before it was prominently taken up by Balzac, Poe, and others). It is indeed an improbable advancement, since the novella, unlike the novel and tragedy of the Romantic era, does not typically induce much empathy for or identification with its characters. Additionally, the novella leaves little room for the evocation of emotional involvement as in many other narrative genres, including that of the ballad. Thus the question arises as to which cultural niche the novella is able to occupy. How could the novella become successful?

My considerations will take their starting point from the simple observation that novellas do not usually have much suspense. Readers generally do not ask themselves: What will happen? Rather, readers find themselves puzzling: what did happen, or what has happened? Even novellas generating suspense about the future often tie tensions about what will happen back to the big questions involving what has already happened. For example, Kleist's Marquis von O... (1808-10) produces suspense near the end of the novella when the Marquise wonders who will show up in response to her newspaper posting and declare himself to be the father of her child. However, this suspense is only a secondary offspring of the question as to how she became pregnant in the first place. That is to say, there is not much suspense in terms of narrated time, or chronology, though one could speak of a suspense of narrative time that goes along with the search for the original cause of the pregnancy. The focus on the earlier event, however, holds true even for novellas that play with open cards and present the event outright - such as the devil's pact in Peter Schlemihl wundersame Reise (1814). Even as the story unfolds, readers keep coming back to the earlier scene and ask what has happened there, when a man trades away his shadow (see Kuzniar).

I wish to put forward five hypotheses, which I will present without much 
pretense in the form of captions for the hasty reader, the kind of reader anticipated by these early novellas, often printed in newspapers such as Kleist's Berliner Abendblatter. I believe that these arguments start from a somewhat agreeable consensus, originating from less contentious ground, and move only slowly to more speculative, but hopefully not unheard-of, hypotheses. In order to proceed by means of argumentation as opposed to the interpretation of individual texts, I will place my abbreviated readings of specific novellas into footnotes where appropriate.

\section{The Event is a retrospective construction}

Most descriptions of the novella situate the event as the center of their considerations, which is not that surprising considering that many novellas boast events that deserve to be called "unheard-of' events, as Goethe famously articulates it in his conversations with Eckermann (January 29, 1827). In what follows, I will capitalize this kind of "Event" to indicate its proximity to the name: it is singular, requires an act of recognition by the reader, and, in its singularity, may well escape our understanding. We can think of Peter Schlemhils wundersame Geschichte; Hoffmann's Sandman (181617), with its primal event of an alchemical experiment gone wrong; and Goethe's novella Die wunderlichen Nachbarskinder (1809), where the attempted suicide of a young woman triggers a young man to declare his love to her "without knowing what he was saying or doing" (Goethe 440). Yet as I wish to show, the case of the event is far from clear. Other novellas, including Goethe's Der Mann von funfzig Jahren (1807-29), Stifter's Abdias (1842), Grillparzer's Der arme Spielmann (1848), or Morike's Mozart auf der Reise nach Prag (1856) do not at first glance offer a clearly marked central event, though closer examination may reveal one. In addition, more than a few of these Events do not strike readers at the moment of their occurrence in the plot or text (neither in narrated time nor in narrative time), but become "unheard- of" in that they radically become disjointed with previous events and provoke puzzlement only retrospectively. ${ }^{1}$

These retrospective reflections are distinct from the after effects of an event that follow a cause-and-effect logic. When the event-earthquake causes destruction, and this destruction frees someone from prison, this is not yet a retrospective reflection. If, however, the prisoner then starts to rationalize his improbable, lucky escape as divine intervention, he enters the realm of a reflective construction of the Event.

In general, the Event is marked by an aura of uncertainty and doubt. Most novellas do not simply present an Event, if even retrospectively, but work hard to negotiate and discuss it, place it in a legal framework, debate it controversially, reflect on it hermeneutically, position it in contexts, frame it, repeat it, or debate it in some other form. These later reflections on the Event do not merely constitute some echo chamber containing the combustion of the Event. Rather, they are somehow part of it; they effectively turn the event into the Event by giving it the attention required for it to unfold or even come into being. Goethe, in his most condensed reflection on the novella, namely, his late text Novelle (1828), draws attention to the constant construction and change of events after the fact. Symbolic of the many turns is the dramatic attack of the tiger, which, shortly after the attack 
and the consequent death of the tiger, turns out to be a mere playful gesture of a tame animal. Goethe's entire novella is in constant motion, in a constant leap, turning back and forth between danger and safety as well as nature and culture, thereby also creating emotive residues with these turns, such as the guilt connected with killing the tiger, the trauma of the uncle, or the love that cannot be expressed. ${ }^{2}$

There are several forms these retrospect reflections on the Event can take. Three forms in particular are common in novellas: 1) an investigation of what truly happened; 2) a judgment that aims to establish how good or bad (beautiful, remarkable, special ...) the Event was; and 3) a repetition that unfolds the Event, perhaps to undo the original event. Kleist's Heilige Cacilie oder die Gewalt der Musik (1810-11) provides a case for the first, investigative, kind of Event constitution. There certainly appears to be a first Event, or to be more precise, the Event consists of the absence of an event, namely, the planned iconoclast burning of a Catholic nunnery that does not take place, as well as the maddening of the ringleaders of the attack. Thus, the Event seems to be the unlikely rescue of the old nunnery, even after the iconoclasts are already inside of it. Why do the ringleaders fail to give the signal for the attack? Two versions seem plausible to explain the (Non-)Event: that of a divine intervention (of the saint of the title) and that of madness as an effect of the "power of music" (as the subtitle of the novella spells out). Indeed, the majority of the novella addresses the ringleaders' mother and her attempts to understand what happened through conversations with different witnesses and stakeholders. However, as is typical for Kleist, these witness accounts cast doubt on both versions. Instead, a rational version of the event emerges between the lines, namely, of a pretense of the brothers to escape the death penalty. ${ }^{3}$ It is only in retrospect that readers can suspect the "true" course of events, even when the mother favors a different explanation.

The second form of Event-construction - by means of judgment - is at the center of various novellas that deal with legal and moral framings of a past event. of course, any later judgment to some degree participates in the construction of the past event. By closing the matter, the Event itself gets changed since it now is a closed event. Even if the judgment is not a judgment in the legal sense but a judgment of taste, the event gets changed by its new attribute (i.e., "sublime"). Of course, it does not require the work of a novella to do this. But novellas can still produce more complex patterns of establishing the Event ex post facto by means of judgment. This is the case when the act of judgment itself (and not the content of the verdict) changes the Event. The Event is thereby prolonged into the future where it has yet to be decided what exactly the Event was, precisely because the reflections change what the Event was/has been. The later point is best clarified by means of an example. Kleist's Michael Kohlhaas (1808-10) unfolds in various legal negotiations of the original event, which, it first seems, consists of the mistreatment of Kohlhaas' horses and consequent denial of justice. This primal event would not have been remarkable had Michael Kohlhaas not insisted on being right and consequently done everything imaginable to get justice, including starting a full-blown war that leads to interventions by Martin Luther and the high king. Hence, the original event was not an Event. It is also not simply the later 
judgment of the event by Koolhaas (namely, that injustice was done to him) that retrospectively raises the status of the first event. Rather, his self-declared righteousness (as a result of his carefully weighed judgment of all circumstances) becomes part of the Event. Thus, the Event itself consists in Koolhaas' reaction to the injustice he experienced, a reaction that produces new injustices. This is a pattern that is duplicated several more times throughout the text where someone (e.g., Luther) judges the previous events in such a way that these judgments and the course of actions they trigger become part of the Event. The story's escalation until the end feels like someone walking through mud with a bigger and bigger tower building under his shoes. That is, the question of what the Event was is still in flux up to the end. Similarly, novellas such as Gotthilf's Schwarze Spinne (1842) consist of several framings (and an actual wooden frame) and responses to the original event of the devil's pact that all prolong the Event.

The third model of retrospective reflections on the Event consists of repetition. Repetition can have many forms. It can be a conscious effort or an effect of forces not controlled by simple planning. Still, in all of these forms, there is some human or human-like agent for whom the event has not yet come to an end. This agent may go back to the original occurrence in a conscious effort, but he or she may also experience repetitions as involuntary acts of memory. A conscious effort of repetition marks Balzac's Adieu (1830), in which a young French woman looses her mental sanity in a dramatic scene when she is separated from her fiance in the Napoleonic retreat from Russia. The loss of her sanity becomes the novella's unheard-of event only in its repetition: her lover, in an attempt to heal her, rebuilds the entire scene of their separation in the midst of battle with several hundred costumed peasants in rural France (see Felman). A non-conscious repetition, by contrast, is at the center of Tieck's Der blonde Eckbert (1797). ${ }^{4}$ It is important to note that not any repetition would constitute a retrospective construction of the Event. This retrospective construction requires a memory function that brings about the repetition. (In light of hypothesis 2, we will have to correct this formulation and say that the memory function can be assigned the role of bringing about the repetition.) Only if the repetition can be thought to be the result of someone (or some collective's ${ }^{5}$ ) memory is the second occurrence truly part of the first occurrence. Put differently, repetition of events requires the assumption of "a psyche," that is, a reservoir of past events that preserves the potency for these events to impact future actions. Hence, it is no surprise that this form of retrospective construction of events is closely linked to Romanticism and its invention of empirical psychology. ${ }^{6}$

These three general forms of retrospective Event constructions often appear in some mixture, but this should not confuse their general distinction. Judgment in itself does not yet constitute a repetition, and neither does the investigation of the true circumstances of an occurrence lead to a repetition in someone's memory. Still, the goal of this sketch is not to establish some new classification, but to observe generally that any later attempts to clarify, explicate, judge, repeat, or revoke the first event at least partially constitute the Event. The retrospective reflection on the Event is not a secondary ornamentation, but rather the movement in which the Event takes place. In general, this retrospective construction implies 
first that there is at least some hermeneutic operation at work recognizing the significance of the prior occurrence; and second, that this prior occurrence needs to be embedded in some context, a context which can only later emerge. In this sense, the novella does the work that readers do in most event-driven stories. Or put differently, the novella anticipates the work of readers who come to terms with and contextualize the given events of a story. Below I will suggest calling this movement a "re-entry" of the text-reader coupling into the text.

This consequently allows for the drawing of a contrast to earlier novellas. In contrast to the Renaissance novella, the Romantic novella does not focus on the characters, as a simple comparison to Boccaccio's so-called Falcon-Novella (1470) reveals. In this novella, which has become a paradigmatic novella for many scholars due to the "thing-symbol" of the falcon, ${ }^{7}$ a lover sacrifices his beloved falcon to serve it as food to his lady love, who recognizes his sincerity through this gesture. ${ }^{8}$ This novella does pose a temporal delay in recognizing the intentions of the knight, but once the recognition takes place, the event is folded back into a mere attribute of the character (see also Walzel; Swales; Remak).

\section{Events take place in the eye of the beholder}

The historic origin of the Romantic and Post-Romanic novella is often traced to Goethe's collection of short texts Unterhaltungen deutscher Ausgewanderter from 1795. ${ }^{9}$ The novellas in that cycle, however, are certainly not typical of what would become the Romantic novella, but instead share more stylistic and thematic affinities with the Renaissance novella. Still, one text included in the collection may indeed prove relevant for the Romantics and the Romantic novella: the final text, simply called Das Marchen (1795). This bizarre little text instantly puzzled and fascinated its audience due to its fantastic characters. Many readers quickly proposed their own interpretations, prompting Goethe to say that only after he had received 99 such readings would he reveal his reading (Goethe 607, in a letter to prince August von Gotha, December 21, 1795). In Das Marchen, the reader is not secondary to the text but pieces it together in different ways, thus producing not one authoritative text but many versions. Even Goethe, it would seem, is merely the 100 th reader of his text. ${ }^{10}$ It is here, and not so much in the actual novellas, that the Romantic novella may find its origin - though of course Goethe's emphasis on the novella must have again recommended this form to its contemporaries. A case in point would be Tieck's famous Der blonde Eckbert, which blends features of the Renaissance novella with the fairy tale. Similarly, the many readings of Kleist's Marquise von 0 ... consider not merely one or two possible fathers, but hold virtually every male figure of the novella accountable as the "true" father (Chaouli; Stephens).

\section{The Event comes about by actively suppressing other renderings of the Event}

The role of the reader of the novella is not simply to discover one hidden truth, as in the related genre of the detective novel - which historically and structurally appears to be an offspring of the novella, beginning with E.T.A. Hoffmann's Fraulein 
Scuderi (1819-21) and followed by Poe's Murders in the Rue Morgue (1841). Instead of engaging in the act of discovery, novellas are concerned with the probable positings of explanations by individual readers. In other words, each rendering of the event suppresses other renderings of what happened. Furthermore, this is part of the structure of the event in that it requires context, subsequent framing, interpretation, and a judgment of what happened. ${ }^{11}$ Most detective novels leave little doubt in the end as to who did it. Novellas, however, usually require an act by the reader to establish what exactly counts as the Event and, conversely, what does not count as the Event but functions as a mere ruse or distraction. This is true for detective-like and also nondetective-like novellas. In Droste-Hulshoffs Die Judenbuche (1842), the ambiguity is marked at the end, when we fail to learn definitively which of the two friends hangs himself and whether justice is thereby served. While either friend might ostensibly deserve at least some portion of the fate that brought them into slavery, there are other events to establish. Still unclear is the question of who committed the murder of the Jew, Aaron, in the first place, although circumstantially, it seems to be the protagonist, who eventually takes flight. (My version of the events is that it goes on the account of the community as a whole. ${ }^{12}$ )

This tendency of determining a course of events with first an explanation of the Event and then the suppression of competing explanations quite often goes so far as to establish the Event itself. Arnim's Der tolle Invalide auf dem Fort Ratonneau (1818) features an extravagant firework-bombardment of Marseille at the hands of three soldiers barricaded in an old fortress. Depending on what readers choose to emphasize, they will either establish the Event in the acts of the madman soldier (the tolle Invalide) or discern the true event in the infidelity of his wife. Should readers discover the clues pointing toward infidelity, they will likely embrace the head wound of the soldier as an attempt to smooth over the "true" Event. The point, in any case, is that the suppression of other explanations of the Event is part of the Event.

At first glance, Goethe's novella Der Mann von funfzig Jahren could appear to be a text without an Event. As peculiar as the situation may be that a man of 50 suddenly views himself as the future husband of his much younger niece, the story proceeds with its own logic and assigns each player a space of action. Nevertheless, I do believe it makes sense to speak of an Event in the case of this novella, though admittedly, only by means of constructing the to-be-expected behavior of all characters. If one does so, only one act falls out of the picture and is thus unheardof, namely, the refusal of the niece to marry her young and appropriate lover at the end (the same could be true for the beautiful widow, though we learn somewhat less about her in the novella). This refusal does not fit the space and logic of actions established by the novella. Even though this refusal or self-denial occurs only at the end of the novella, the framing novel, Wilhelm Meisters Wanderjahre oder die Entsagenden, as a whole addresses the discrepancy, famously calling it an act of Entsagung (renunciation), as intimated by the subtitle of the novel. Establishing this - or other - Events changes the entire text.

So far, I believe I have not said much that is controversial, at least as long as one omits some of the specific, and probably somewhat cryptic, claims about 
individual novellas. One could, perhaps, object that the retrospective construction of the Event (hypothesis 1) by the reader (hypothesis 2) that actively suppresses other renderings of the Event (hypothesis 3) is not so much the discovery of the Romantic novella, as an almost universal feature of complex narratives. While it may certainly be true that these retrospective constructions of Events are always possible in works of fiction, my point is that the Romantic novella actively stages this retrospective construction, making it part of the novella itself. In this sense, the relationship of Event (text) and reader (interpretation) is duplicated within the novella; or, to put this in the language of German systems theory, the novella as a form distinguishes itself through a re-entry of the event-reader-relationship. Within the novella, the reader-function is internalized by way of discussion, negotiation, and contextualization of the Event. Quite a few novellas devote the majority of their text to such retrospective negotiations of the Event (Kleist's Michael Kohlhaas and Der Zweikampf (1811), Chamisso's Peter Schlemhil, perhaps Morike's Mozart auf der Reise nach Prag with Mozart's long justification of why he plucked the orange from its tree).

\section{There is no Event. The Event is the limit of the novella}

The hypotheses up to this point may not be controversial, but they lead to a peculiar consequence. What does it mean that the Event is a retrospective construct? It means that the Event exists by virtue of being explained and contextualized. To be sure, only after, or even because of, an explanation does the Event in its full bizarreness come into light, but as a result of these very explanations the Event is rendered less potent. The found fathers in Marquise von $O$..., as established by various readers and their various readings, both highlight and ultimately limit the Event. Precisely the gesture which establishes the Event undermines its radical event-ness. As it involves framing and suppressing other versions of the event, the peculiar gesture by which the Event comes into being assures that the Event, even in its exceptionality, does fit its context. The Event, by virtue of this fit, is not radically singular, but an aberration, a play with probability, as Rudiger Campe describes it (Campe). In short, we have to conclude that the Event does not exist, at least not as the grand "Event" in capital letters. The novella posits the question of the Event only to demote it to a mere event among others. Perhaps this is why the "unheard-of event" has such a special status in the novella: because it is radically exceptional and perhaps impossible (consider Derrida).

One can express this consequence as a play of action and reaction. Whereas the drama of and before the age of Romanticism stressed unprovoked actions or actions that go against the dominant regimes (Schiller's Die Rauber [1781] and Wilhelm Tell [1804], Goethe's Gotz von Berlichingen [1773], even Lenz's Der Hofmeister [1774]), the novellas show how something which at first appears to be a free action may in fact turn out to be a mere reaction. The radical actions of individuals, even highly improbable ones, "make sense" to us once we frame them in such a way that they emerge as reactions to prior events or stimuli. By revealing action to be in effect reaction, that is to say, by embedding the action in extenuating circumstances, agency is softened, excused. Consequently, each action is 
incomplete without the prior events to which it may or may not react. The trick of the novella is to reserve the work of turning action into reaction for the reader. Moreover, because of the potentially large number of possible prior events and contexts to which each action could respond, the door to manifold possibilities is opened. Thus, at the risk of sounding paradoxical, I would suggest that action appears in the Romantic novella only to disappear and prove in actuality to be reaction.

This structure of the less-than-radical event may also be optimal for human memory. In recent experiments, test groups were asked to retell fairy tales with no event, or with events that are either "maximally counterintuitive" or "minimally counterintuitive." It turned out that those narratives with minimally counterintuitive events were most faithfully remembered over longer stretches of time and passed on over many generations of story-telling (Norenzayan et al.). The radical, unexplainable Event was often tossed out altogether or changed in later retellings of the story, whereas the minimally counterintuitive event that was not explained but could be explained survived the retelling without many changes.

Strategic considerations and manipulations are one of the forms by which this turn from action to reaction can take place. This is where Kleist rules. Kleist's novellas, in my opinion, often suggest (but by no means compel) a reading that reveals a ruse. I have already presented my reading of Die heilige Cacilie as a clever cover-up by the brothers, and my personal reading of Marquise von O. likewise exposes such a conscious deception. (The Marquise did indeed engage in an incestuous relationship with her father, and so places the ad in the paper not as an effort to appear innocent, but rather to plant the idea that she is merely trying to cover up some silly but harmless affair. Her shock when the count appears makes sense, since he is the only one she cannot refuse. If a lower-class person such as the hunter would have come forward, the family would have customarily paid him off.) Similarly, the ghostly apparitions in Bettelweib zu Locarno (1810) can be read as manipulations by the wife, who, as we learn, is not too happy living away from the city and who may react to the financial misfortunes of her current husband: she, the only surviving witness, flees to Milano in the end, perhaps along with the last visitor to their castle. I wish to stress not the correctness of these readings, but the impulse inducing me as reader to establish them, argue for them, suppress other readings, and ultimately take away that which is most fascinating about these novellas, namely, the surprising, puzzling, and sublime aspects that comprise the Event. ${ }^{13}$

Many novellas offer various registers to explain the action as a reaction. As indicated, the madman soldier in Arnim's Der tolle Invalide could be acting in reaction to the infidelity of his wife, to the head injury he received, or to his stubborn nature not permitting him to take back his word. Although the novella is not clear as to whether the action of the soldier is a conscious effort or not, it is very clear about offering possible contexts that transform his action into reaction.

Novellas with more magical Events, such as the pacts in Chamisso's Peter Schlemihl or Gotthilf s Schwarze Spinne, appear to be condensations of the basic wish-situations of those who enter into (bad) bargains. Peter Schlemihl wishes to have the power and wealth of his uncle, while the villagers hope to get out of their 
predicament. Hence their action is propelled by power of their will to find a way out of a hopeless case, which then magically generates the pact. It would even seem to be the case that this action-reaction dynamic controls the production of the wish.

One of the most prominent cases of the action-reaction dynamic is the invention of trauma in Romanticism, the idea that certain horrific events in the past can force human beings to involuntarily repeat or re-experience these same events later in life. Although this is not the place to trace the complex history of this idea in Romanticism (see Pfau; also Breithaupt, "Invention of Trauma"), the fact that psychological trauma prior to its medical history is first recognized and functionalized in literary texts bears mentioning. Within the context of continental Europe, this phenomenon can be found in novellas such as Hoffmann's Der Sandmann, Fraulein Scuderi, and Balzac's Adieu. In these novellas, the event inflicting the initial wound changes the protagonists or central characters in such a way that they either appear to have lost sanity (Adieu) or react to specific stimuli that trigger non-conscious, self-destructive programs of action (the jewels in Fraulein Scuderi or the copula in Der Sandmann ${ }^{14}$ ). In this sense, later actions are but reactions to the first event. However, the first event hardly qualifies as the "Event" either, since it unfolds its power mostly in repetition. Without the later repetition, the first event would have been sad, tragic, or bizarre, but no more.

Such trauma-narratives increase the arsenal of narrative techniques to convert actions into reactions and demote Events into mere occurrences. By revealing how human action can amount to a repetition of past experiences, every human action can be suspected to constitute mere repetition.

Conversely, in light of the genre of the novella and its dynamic, it makes perfect sense that "trauma" appears to be first recognized/discovered/invented along with the novella. The productivity of the Romantic novella relies upon readers and their ability to detect causes and determine regularity behind idiosyncratic human action. For this reason, positing prior "traumatic" events and speculating about the psyche as an apparatus of repetition could partly be a byproduct of readers being puzzled by novellas. At the very least, it was most likely not shell-shocked veterans from the Napoleonic wars that elicited these insights.

\section{The novella excuses the self}

In the landscape of genre formation, the German Romantic and realist novella always had a peculiar status as being mostly limited to the Germanic canon. In the context of Western narrative literature in the nineteenth century, the German experimentation with novellas seems like a little speck that gets washed away by the flood of novels. And yet, it reveals a pattern that is central to the success of the novel in the nineteenth century: novels may not present unheard-of events, but they constantly provoke the question as to why someone is doing something and what intentions they pursue. And quite often, the answer to these questions is suspended, up for interpretation, and waiting for a later context that has yet to emerge. This is where the retrospective constitution of the events comes in, a business in which the novella excels. I do not mean to say that the modern novel could not have emerged in the nineteenth century without the novella; the point is that the novella allows readers to practice the cognitive pattern of the 
retrospective constitutions of events, a pattern they needed to come to terms with before they were fully fit for the modern novel. Still, this is not sufficient to explain the German novella in Romanticism.

The rise of the novella in Germany has, among other things, been attributed to the secularism of the age, to previous aesthetic trends (for and against Classicism, Romanticism), to the French Revolution or the French occupation of Germany, industrialism, the pocket book, accelerations of modern life, and the rise of newspaper circulation. ${ }^{15}$ In light of the above hypotheses, we need to raise the question about the cultural context and the popularity of this genre anew. The novella certainly does "cultural work," to use an overused phrase, by turning the Event into a mere effect and by converting actions into mere reaction: it absolves the individual from responsibility.

The late eighteenth century and the early nineteenth century witnessed an unprecedented rise of expectations of and demands on the individual (Luhmann). In the preceding periods, individuals were assigned their place in a hierarchically organized society by birth. They were part of a social class, a large family, a religion, and a clear professional trajectory. However, all this changes at the end of the century, when people became free to choose their professions and thus acquired newfound social mobility (the Standeordnung regulated professions until 1795 in Prussia), and when the social bonds of the large family increasingly gave way to the nuclear family. These changes go along with new conceptual pressures arising from the notions of selfhood that demand autonomy and originality (Wahrman). In the German context, this begins with Storm and Stress and culminates in Idealism.

And this is also where the novella comes in. If indeed the work of the novella consists of transforming actions into reactions, it is only fitting that it would appeal to a form of individuality forced constantly to prove itself by asserting its selfsufficiency and independence. Hence, my suggestion is to place the novella in the context of the compulsions that derive from the notion of "the self" and from the focus on individuality in general. One could at least speculate that it is because of the strong demands on "the self" as a leading concept in Romanticism in Germany that the modes of contex- tualization of actions as mere reactions could have such an appeal as a counter-dynamic. The novella allows people to see that not all action is free action and that there are always ways to construct contexts that establish a seemingly spontaneous action as a mere reaction. Novellas soften our expectations of the individual. They provide relief.

To be sure, not all novellas deal with selfhood and the understanding of free human action. However, quite a few do, at least indirectly, such as the traumanarratives, which ex negativo reveal that there are strong limits to free, unprepared human action. Even novellas that deal with seemingly divine forces turn out, in the mind of suspicious readers, to be driven by human interests. In the case of the more fantastic novellas (such as many texts by Tieck, Chamisso's Peter Schlemihl, or Gotthilfs Schwarze Spinne), the fantastic events mirror what characters could wish or hope for. In this sense, the events are reactions to actual wishes, and these wishes in turn are the result of concrete pressures on near-hopeless individuals (as in Die schwarze Spinne) or of seductions (Tieck's Runenberg, Chamisso's Peter Schlemhil). This turn from the fantastic Event to mere strategic interests, wishes, 
or desires structurally mimics the move from strong action to mere (strategic, planned) reaction.

Siegfried Kracauer has characterized the work of the detective novel as a huge demotion of the grand individual, that is, the sublime and unknown criminal, to a mere humble human being, once the detective discovers his identity (Kracauer). The challenge for the reader of the novella, similar to the detective, is to contextualize the Event, to frame it, and thereby to rationalize and explain it. This move away from strong spontaneous action and selfhood goes along with an increased recognition of the role of the observer, the reader who completes the novella (see hypothesis 2). Literary and philosophical texts have probably always given special status to the activity of observers. However, the increased attention paid to the "activity" of the observer in the early nineteenth century is remarkable. It condenses itself in the invention of new figures or professions, such as the critic, detective, intellectual, and investigative journalist (Fohrmann) - all only inhibited versions of a self.

\section{Conclusion: the novella and the question of fiction}

These last reflections lead us to questions that concern the nature, origin, and structure of fiction and narrative in general. It is only fair to ask how the genre of the novella fits into these larger issues.

The past decade has been especially rich in discussions of the origin and function of story-telling as a whole. A core question of this debate is whether the ability to tell stories could have been a driving force in the evolution of the human brain and the development of culture. Telling stories, the original suggestion ran, involves a rather complex form of thinking that exists parallel to scientific rationality. Since this theory was pioneered by Jerome Bruner (see also Dautenhahn, who coined the name Narrative Intelligence Hypothesis) evolutionary biologists, cognitive scientists, and narratolo- gists have put forward different understandings of the nature of narrative. The following benefits, with concomitant beliefs about the core structure and purpose of narrative, have been put forward as hypotheses: preparation for future possibilities through playful use of imagination (Eibl; Boyd), social cohesion by means of gossip and social communication (Dunbar), and social cohesion by means of ensuring that abusers of the system (criminals and free-riders) receive deserved punishment (Flesch). ${ }^{16}$

These large-scale theories have direct implications for fiction as well, even if only a few of these authors draw on them explicitly (Boyd; and especially successfully, Flesch). William Flesch's argument deserves special consideration since his claim deals directly with issues we encounter in virtually all novellas, namely, questions of guilt, responsibility, and punishment. Flesch suggests that narrative fiction is the place where we, as social beings, want to make sure that those who abuse the social system get their deserved punishment. This includes the actual wrong-doers as well as the free-riders and the bystanders, who do nothing to punish the wrong-doers and free-riders. Flesch can list an impressive amount of texts, including biblical accounts, that follow this logic. I am still hesitant to embrace this hypothesis, however, since it assigns a purely negative value to fiction: punishment. The function of literature thus would be merely to compensate 
for the negative effects of tight-knit communities. I wonder whether narratives and fiction may not have a more positive function, some aspect that can account for the joy and captivating aspect of literature as well. Also, it bears mentioning that most novellas are not about punishment (although, perhaps, Der blonde Eckbert, Kleist's Erdbeben in Chili, Fraulein Scuderi, and Schwarze Spinne could be counted as such, depending on one's reading), but rather about people escaping from punishment and pursuing happiness (see Eichendorffs Aus dem Leben eines Taugenichts [1826]).

If we want to understand how the novella could be situated with respect to the question of the social function of literature, it is helpful to consider accounts that distinguish different models of narrative fiction. Hannelore Schlaffer, for example, emphasizes the creative aspects of the novella as its strength (Schlaffer). Vivasvan Soni has recently proposed to distinguish two core models of narrative literature: tragic narratives and trial narratives. Whereas tragic narratives deal with the pursuit of happiness, trial narratives suspend questions of happiness and instead put the protagonist through a test or series of tests. In this context, the novella would have to be placed on the side of the trial narrative. Excluding the consideration that novellas really "test" the reader to explain the Event, novellas do indeed provide a test for the protagonist, a test which does not consist of passing some mark and establishing his superior character, but rather of limiting his involvement. Passing the test in the novella consists of revealing that in reality one was not tested. This is what Kleist's Marquise, the would-be iconoclasts, Morike's Mozart, and even Goethe's neighbor's boy and the niece, all aim for.

In this sense, novellas do not offer the correct way of acting. Instead, they show how one can get off the hook by revealing the contexts that explicate one's action, the extenuating circumstances, the excuses that one could only do so much. And here indeed may be a more immediate evolutionary advantage to narrating, namely, its usefulness for getting one out of dicey situations. By providing an "excuse," one may escape punishment for risky behavior. Thus the novella foregrounds a general feature of narrative: once there is narrative, there is not just a plurality of possible plot developments, but also consideration of linguistic nuances when weighing causation, agency, and responsibility. Once an action appears as mere reaction, that is, once an action or event is framed by contexts that explicate it, issues of responsibility and agency are typically softened and may not be attributed to one offender alone (or the blame may have shifted from one to another). In short, the Romantic novella is the genre of general excuseablity.

\section{Acknowledgements}

My thanks for critical feedback and inspirations go to the students of my class on the novella in fall 2009, as well as Christopher Chiasson, Andrea Meyertholen, and Johannes Turk.

\section{Notes}

1. In fact, two of the most often-mentioned features of the novella already in the 1820 s were the "Begebenheit" (event) and the "reflexive Element" (reflexivity). See Schroder 119-151. 
2. For a reading of the moment of "hearing" in this "unheard-of event" and the end of the Novelle, see Auer.

3. It is mentioned in one of the witness accounts, as if it were of little importance, that the armed national guard has arrived at the nunnery during the crucial night. Hence, giving the signal for attack would have lead to the crushing defeat of the iconoclasts. This laconic reference to the guards, along with further details that indicate that there is a mole in their ranks, reorients the Event as a mere survival strategy: there is no escape for the brothers, except pretending madness, a madness that is opportune for the Catholic church (see Breithaupt, "Wie Institutionalisierungen...")

4. The text does not so much feature one event as much as it repeats one structure four times, namely, the running away from home through some fog or forest to reach a new home and establish a new family. However, at this new home, an element of the former home/family reappears as a return of the repressed. This structure of repetition corresponds to the condensation of the characters into the two the bert-characters (Eckbert, Berta) and the alter-characters (Eltern, Alte, Walter). Here, the repetition emphasizes the repeated structure of a guilt/trauma-induced flight and murder.

5. See the reading of Die Judenbuche below.

6. On this point, see the witty account by Sloterdijk.

7. The favoring of the Falcon goes back at least to 1871, when Paul Heyse provided his "Falkentheorie" in the introduction of the Der Neue Deutsche Novellenschatz.

8. For more differences between the Renaissance novella and the Romantic novella, see Klein; Remak; Swales.

9. Andreas Gailus argues in a rich text that Goethe's Unterhaltungen deutscher Ausgewan-derter are the starting point for the Romantic novella. His argument is that the Unterhal- tungen "dramatize the disturbance of a system by a foreign body" (739) and that the German Romantic novella in general is based on "an excessive and traumatic element that threatens the unity of an organized whole from within" (740). Curiously, this argument does not so much derive from a reading of the novellas in Goethe's collection (those are hardly mentioned), but from their historic context (French Revolution) and textual frame (namely, the "conversations"). In fact, it seems that Gailus' hypothesis in its generality fits the tragedy of the time better than the actual novellas and may be more of an attempt to explain romanticism, or literature as such, than the novella. Also, I have some doubt whether the structure identified by Gailus demarks the hotspot of the novellas or their general occasion. While I bracket Gailus' arguments for the novella, they may well offer a productive way to think about a common form of many literary texts and genres, especially during the early Romantic period.

10. The emphasis on plurality of readings may also be the explicit topic of the text itself, at least if I am correct to read Das Marchen as an allegory of Kant's philosophical project, which Goethe read intensely at the time of writing his fairy tale. The three statutes of kings thus appear as renderings of the three critiques; and the bridge symbolizes the project of the Third Critique. Goethe's critical point vis-a-vis Kant would then be the hidden fourth statue, built from the metals of the other three mixed together: instead of order, we start from a complete mixture which empowers the observer to himself produce order. For a full reading, see Breithaupt, Jenseits der Bilder, 97-130.

11. Johannes Klein, in his large overview of German novellas, also views a fundamental ambivalence and consequent call of judgment at the heart of the novella. See his archetypal scene of the novella in which a mountaineer, superstitiously fearing danger, makes a detour, only to die in an avalanche. It is up to the reader to establish the novella between human action and divine intervention (Klein 4-5). 
12. Strange things happen in the forest. When a person crosses the forest on the way from A to B, they may easily disappear, or they may experience an event acoustically. Friedrich's father, the choleric drunk, disappears on a cold winter night when he makes an inebriated return from a wedding, only to be found later, frozen. Hearing suspicious noises, his son wants to open the door, but is not allowed. This still seems accidental until this pattern of people disappearing in forests with only sounds to be heard repeats itself. Several murders occur too. Retrospectively, it may appear that the murder does not go on the account of Friedrich, but rather on the community as a whole, which also punished his abusive father.

13. Gerhard Neumann describes some of these scenes as the "urscenes" of Kleist's novellas and anecdotes. Neumann notes how scenes of competing registers of perception (seeing, feeling) go hand-in-hand with the establishing of borders and opposites (male-female, white-black, citizen-foreigner, etc.) and their dissolution or bastardization (136).

14. Most readers agree that Nathaniel to some degree reacts to the primal alchemist scene in which his father dies. But how exactly does this happen? It seems to me that Nathaniel is reacting, above all, to the mother's statement, with which she aims to usher them to bed. After saying that the "sandman" comes, she corrects herself: "There is no sandman, my dear child ... When I say the sandman is coming, all that means is that you are sleepy and cannot keep your eyes open, as though someone had sprinkled sand into them" (Hoffmann 87). This clause posits an equation. "Sandman" only "means" that the kids are tired. The awkwardness of this statement lies first in the fact that the mother introduces the sandman only to erase him thereafter, and secondly, that the children hear the arriving footsteps (of the alchemist), which seem to indicate the real existence of the sandman. The children conclude "that she had denied the sandman's existence only so that we should not be afraid of him" (Hoffmann 87). In short, the equation "sandman" and "being tired" causes suspicion. And this is the minimal formula of the primal event. Whenever an equation is made, this raises suspicion. Whenever someone attempts to calm Nathaniel by means of an equation ( $\mathrm{x}$ is really $\mathrm{y}$ ), he reacts with panic and sees evil coming. That is, whenever there is a copula ("is" or "means") or a man named Coppelius or Coppola, something goes wrong in his mind. The equation becomes traumatic and produces monsters.

15. For the tension between the instantaneous information versus the lasting narrative, see Benjamin.

16. For an overview of these scientific accounts of narrative, see Scalise Sugiyama.

\section{References}

Auer, Michael. '“...jeder in seiner Art.' Das Unerhorte in Goethe's Novella." Unpublished manuscript.

Benjamin, Walter. Selected Writings. Vol. 3. 1935-38. Ed. Howard Eiland and Michael W. Jennings. Cambridge, MA: Harvard UP, 2002. Print.

Boyd, Brian. On the Origin of Stories. Evolution, Cognition, and Fiction. Cambridge, MA: Harvard UP, 2009. Print.

Breithaupt, Fritz. "The Invention of Trauma in German Romanticism." Critical Inquiry (Fall 2005): 77-101. Print.

—. Jenseits der Bilder. Goethe Politik der Wahrnehmung. Freiburg: Rombach, 2000. Print.

—. "Wie Institutionalisierungen Freiraume schaffen (Kleists Marquise von O..., Die heilige Cacilie und einige Anekdoten." Ed. Nikolaus Muller-Scholl and Marianne Schuller. Kleist Lesen. Bielefeld: Transcript, 2003. 209-42. Print.

Bruner, Jerome. Actual Minds, Possible Words. Cambridge, MA and London: Harvard UP, 1986. Print. 
Campe, Rudiger. Spiel der Wahrscheinlichkeit. Literatur und Berechnung zwischen Pascal und Kleist. Gottingen: Wallstein, 2002. Print.

Chaouli, Michel. "Irresistible Rape: The Lure of Closure in 'The Marquise of 0...'” The Yale Journal of Criticism 17.1 (2004): 51-81. Print.

Dautenhahn, Kerstin. "The Narrative Intelligence Hypothesis: In Search of the Transactional Format of Narratives in Humans and Other Social Animals." Lecture Notes in Computer Science 2117 (2001): 248-66. Print.

Derrida, Jacques. "Une certaine possibility impossible de dire l'evenement." Ed. Gad Soussana and Alexis Nouss. Dire l'evenement, est-ce possible? Paris: L'Harmattan, 2003. 79-112. Print.

Dunbar, Robin. Grooming, Gossip, and the Evolution of Language. Cambridge, MA: Harvard UP, 1996. Print.

Eibl, Karl. Die Entstehung der Poesie. Frankfurt: Insel Verlag, 1995. Print.

Felman, Shoshana. Writing and Madness: Literature/Philosophy/Psychoanalysis. Ithaca, NY: Cornell UP, 1985. Print.

Flesch, William. Comeuppance: Costly Signaling, Altruistic Punishment, and Other Biological Components of Fiction. Cambridge, MA and London: Harvard UP, 2007. Print.

Fohrmann, Jurgen. “Die Erfindung des Intellektuellen.” Ed. Jurgen Fohrmann and Helmut J. Schneider. 1848 oder das Versprechen derModerne. Wurzburg: K \& N, 2003. 113-29. Print.

Gailus, Andreas. "Form and Chance: The German Novella." Ed. Franco Moretti. The Novel. Vol. 2. Forms and Themes. Princeton, NJ: Princeton UP 2006. 739-76. Print.

Goethe, Johann Wolfgang von. Werke. Ed. Erich Trunz. Vol. 6. Munich: Beck, 1981. Print.

Hoffmann, E.T.A. Tales of Hoffmann. Trans. R.J. Hollingdale. London: Penguin Classics, 1982. Print.

Klein, Johannes. Geschichte der deutschen Novelle. Von Goethe bis zur Gegenwart. Wiesbaden: Franz Steiner, 1954. Print.

Kleist, Heinrich von. The Marquise of $\mathrm{O}$ - and Other Stories. Trans. David Luke and Nigel Reeves. London: Penguin Classics, 1978. Print.

Kracauer, Siegfried. Der Detektiv-Roman. Ein philosophischer Traktat. Frankfurt: Suhrkamp, 1979. Print.

Kuzniar, Alice. "'Spurlos ... verschwunden': Peter Schlemihl und sein Schatten als der verlorene Signifikant." Aurora 45 (1985): 189-204. Print.

Luhmann, Niklas. "Individuum, Individualitat, Individualismus." Gesellschaftsstruktur und Semantik. Studien zur Wissenssoziologie der modernen Gesellschaft. Vol 3. Frankfurt: Suhrkamp, 1989. 149-258. Print.

Neumann, Gerhard. "Anekdote und Novelle: Zum Problem literarischer Mimesis im Werk Heinrich von Kleists." Ed. Tim Mehigan. Heinrich von Kleist und die Aufklarung. Rochester, NY: Camden House, 2000. 129-57. Print.

Norenzayan, Ara, et al. "Memory and mystery: The Cultural Selection of Minimally Counterintuitive Narratives." Cognitive Science: A Multidisciplinary Journal 30 (2006): 531-53. EBESCOHost EJS. Web. 20 May 2010.

Pfau, Thomas. Romantic Moods. Paranoia, Trauma, and Melancholy, 1790-1840. Baltimore: Johns Hopkins UP, 2005. Print.

Remak, Henry. Structural Elements of the German Novella from Goethe to Thomas Mann. New York: Peter Lange, 1996. Print.

Scalise Sugiyama, Michelle. "Reverse-Engineering Narrative: Evidence of Special Design." Ed. Jonathan Gottschall and David Sloan Wilson. The Literary Animal: Evolution and the Nature of Narrative. Evanston, IL: Northwestern UP, 2005: 177-96. Print.

Schlaffer, Hannelore. Poetik der Novelle. Stuttgart: J.B. Metzler, 1993. Print.

Schroder, Rolf. Novelle und Novellentheorie in der fruhen Biedermeierzeit. Tubingen: Max Niemeyer, 1970. Print. 
Sloterdijk, Peter. Der Zauberbaum. Die Entstehung der Psychoanalyse im Jahr 1785. Epischer Versuch zur Philosophie der Psychologie. Frankfurt: Suhrkamp, 1985. Print.

Soni, Vivasvan. "Trials and Tragedies: The Literature of Unhappiness (A Model for Reading Narratives of Suffering)." Comparative Literature 59.2 (Spring 2007): 119-39. EBESCOHost EJS. Web. 20 May 2010.

Stephens, Anthony and Yixu Lu. "Die Verfuhrung des Lesers im Erzahlwerk Kleists." Kleist-Jahrbuch 1994: 104-18. Print.

Swales, Martin. The German Novella, Princeton, NJ: Princeton UP, 1977. Print.

Wahrman, Dror. The Making of the Modern Self. New Haven, London: Yale UP, 2004. Print.

Walzel, Oskar. Das Wortkunstwerk. Darmstadt: Wissenschaftliche Buchgesellschaft, 1968. 
